\title{
Improving The Critical Thinking Ability of Students to Solve Mathematical Task
}

\author{
Hasan Basri ${ }^{1 *}$, Abdur Rahman As'ari ${ }^{2}$ \\ ${ }^{1}$ Pendidikan Matematika, FKIP, Universitas Madura, Jalan Panglegur Km 3 No 5, \\ Panglegur, Tlanakan, Kabupaten Pamekasan, Jawa Timur 69317, Indonesia. \\ ${ }^{2}$ Pendidikan Matematika, Pascasarjana, Universitas Negeri Malang, Jalan Semarang 5 Malang 65145, \\ Indonesia \\ *E-mail: hasan_basri@unira.ac.id
}

Article received : 24-07-2018, article revised :01-09-2018, article published:07-09-2018

DOI : 10.25273/jipm.v7i1.3013

\begin{abstract}
This study aims to describe students' critical thinking skills before and after the learning process. Analysis of critical thinking skills in this study based on components of critical thinking evaluation, inferences, explanations, and self-regulation. This type of research is descriptive research with a qualitative approach. The research subject consisted of 2 students with low critical thinking abilities based on task 1 given at the beginning of learning, besides that good communication was also one of the subject selection criteria. The results of the analysis showed that both research subjects SS and FT experienced an increase in their critical thinking abilities, this was evident from each indicator critical thinking evaluation, inferences, explanation, and self-regulation. In each indicator of critical thinking, the research subject is able to demonstrate the ability to do evaluation, inferences, explanation, and self-regulation, this is certainly very different from the initial conditions of research subjects where they have not been able to do evaluations, inferences, explanation well. One of the things that allows an increase in critical thinking skills is the subject of teaching and learning activities, namely by giving task that require students to practice their critical thinking skills.
\end{abstract}

Keywords : Improving; Ability; Critical Thinking; Mathematical Task.

\section{INTRODUCTION}

Current technological developments allow one to get information very easily and quickly. All types of information can be accessed by each individual without being hampered by distance and time by using the internet. The truth of an information is certainly a benchmark for someone to accept or reject the information. But as we know there is no guarantee that information spread on the internet is true or false. According to Asari (2014) critical thinking allows each individual to sort and choose valid and reliable information that has mingled with hoax information (lying).

Critical Thinking has been the focus of research by several researchers (Akgun \& Duruk, 2016; Aktaş \& Ünlü, 2013;
Rasiman, 2015; Rosnawati, 2015). Aktaş \& Ünlü (2013) found that the critical thinking skills of teacher candidates are at the middle level, as well as low on deduction and assumption identification aspects. Rasiman (2015) conducted critical thinking skills in prospective mathematics teacher candidates who were divided into 4 levels namely LCTA-0, LCTA-1, LCTA-2 and LCTA-3. Rosnawati (2015) found a valid and reliable model of critical thinking. While Akgun \& Duruk (2016) found that the critical thinking disposition of prospective teachers was low. Some of these studies indicate the importance of critical thinking, so it needs to be studied and examined in depth.

The ability to think critically is very important for students because it is a basic competence in the curriculum in Indonesia. 
In addition Cottrell (2005) states that almost everyone, in their daily lives, always uses some of the thinking activities contained in critical thinking. Emir (2009) states that when critical thinking is part of education, students are not only more academically successful but they are also more positive in their social relations. Rosnawati (2015) states that critical thinking is one of the most important thoughts that students must have because critical thinking will make a person easier to process and use the information obtained to solve problems.

Besides that, critical thinking also involves the logic of the right reasoning and the ability to separate facts from opinions Chukwuyenum (2013). Jacob (2012) added that critical thinking will encourage students to think more deeply and solve problems in school or in the context of everyday life, which is very important to note that critical thinking skills are not only used in school contexts but also in everyday life. this day further emphasizes the importance of critical thinking for students. Therefore, we need to understand more deeply about critical thinking. Some definitions related to critical thinking, including Ennis (2011) states critical thinking as logical and reflective thinking that is focused on making decisions that must be trusted or what should be done. Watson \& Glaser (2010) states that critical thinking is the ability to identify and analyze problems, and find and evaluate relevant information to reach appropriate conclusions. While Facione (1990) defines critical thinking as the ability to absorb and filter existing phenomena

Regarding critical thinking skills some experts give several different opinions regarding the components in measuring critical thinking skills. Facione (1990) describes critical thinking skills in six components, namely: interpretation, analysis, evaluation, inference, explanation, and self-regulation. Watson \& Glaser (2010) describes critical thinking skills in five abilities, namely: Inference, Recognition of Assumption, Deduction, Interpretation and Evaluation of Arguments. While Ennis (2011) describes the components of critical thinking skills, namely: Focus,
Reason, Inference, Situation, Clarity and Overview.

This study used the components of critical thinking skills delivered by Facione namely: interpretation, Analysis, Evaluation, Inference, Explanation, and Self-Regulation. But not all components will be studied more deeply, the researchers determine the components of critical thinking skills that are most preferred are evaluation and inference. In addition, the provision was also supported by a statement from Ruggiero (2012), Peter (2012), and Snyder \& Snyder (2008) which stated that the core of critical thinking ability is evaluation. Thus, in this study researchers only focus on 4 indicators, namely evaluation, inference, explanation, and self-regulation

Evaluation is the ability to assess the credibility of a statement; Inferences are the ability to give logical reasons for drawing conclusions; explanation is the ability to present results clearly and coherently; selfregulation is the ability to conduct selfassessments, cross-check answers and correct errors.

Based on research data related to critical thinking skills, it was found that the critical thinking skills of prospective teachers / students are still in the low category (As'ari, Mahmudi, \& Nuerlaelah, 2017; Hidayanti, 2016). Various efforts have certainly been done in order to improve critical thinking skills among the use of learning models (Chukwuyenum, 2013; Firdaus, Kailani, Bakar, \& Bakry, 2015; Palinussa, 2013). This study will show how the development of students' critical thinking skills, after participating in learning to improve their critical thinking skills. The tasks given during learning are also in the design to improve students' critical thinking skills.

\section{METHODS}

This type of research is descriptive with a qualitative approach that aims to describe and analyze a phenomenon, event, social activity, attitudes, beliefs, perceptions, thoughts of individuals both individually and in groups. Descriptive research describes what it 
is about a variable, symptom or about a situation. The study was conducted on S2 students who are a collaboration class with East Java Province, all students in this class are teachers who have had NUPTK from various regions in East Java.

The collaboration class with East Java Province consists of 20 people, consisting of 11 men and 9 women. Learning in this class was conducted by 2 Mathematics lecturers at Malang State University. Researchers act as observers who monitor activities in the learning process. During the learning process that took place in 16 meetings, the instructor directly stated that one of the goals in learning that was carried out was to improve students' critical thinking skills. During the learning process students are asked to work on the tasks that have been devised to foster their critical thinking skills.

During the learning process there are 15 tasks that have been collected by the researcher, both the tasks done individually and the tasks carried out in groups. All assignments from students were scanned using the "cam scanner" application and then shared in the previous "KAPITA SELECTA" telegram group. Activities in this group itself have been actively monitored since 28 May 2017 and ended on 15 September 2017. In this group the teaching material presented with power points was shared and downloaded by all students, all tasks given by the teacher were also collected in this group. One feature of task collection through this telegram group is that the collection time can be detected easily.

Subjects in this study were selected based on the initial ability which can be seen from the work of a student's assignment, besides good communication from students is the basis of consideration in the selection of subjects. Subjects to be chosen are students with low critical thinking skills, this is done to see the development of students' critical thinking skills. For students with high ability and not being selected, this is done because the development of high and medium students' critical thinking skills will certainly be difficult to identify. Based on the indicators of the selection of the research subjects, 2 subjects were selected.

The instruments used in this study are the 5th and 10th assignments, the 5th assignment is chosen because it is assumed that students have experienced a slight change in their perspective after several previous meetings, while the reason for choosing the 10th task to see how the development of students' critical thinking skills at the end of learning is. In addition, the material content in the assignments given is one of the considerations in the selection of tasks to be analyzed. Data obtained from the results of the work of research subjects downloaded from the telegram group. Following the 5th and 10th task used in this study can be viewed on picture 1 below.

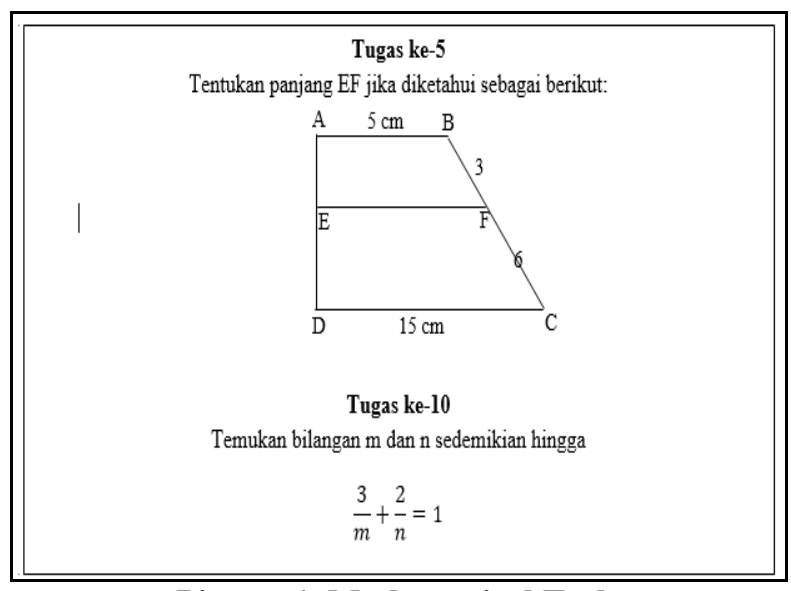

Picture 1. Mathematical Task

Furthermore, the interview process was carried out to the subject to clarify the test results and obtain data especially identifying indicators of critical thinking abilities that were not visible from the test results of the research subject. Interviews carried out by researchers both directly and indirectly, directly means that researchers and subjects conduct oral communication directly while indirect interviews are carried out by sending voice messages via WhatsApp (WA) to the research subjects. These data are then analyzed and used to describe the development of critical thinking skills of research subjects. 


\section{RESULT AND DISCUSSION}

Based on the results of the analysis of the initial assignments of students, as well as good communication considerations, 2 subjects, female subjects with "SS" initials and male subjects with the initials "FT" will be examined more deeply. The following is a description of the initial tasks that were carried out by 2 subjects selected in this study can be viewed on picture 2 and picture 3 .

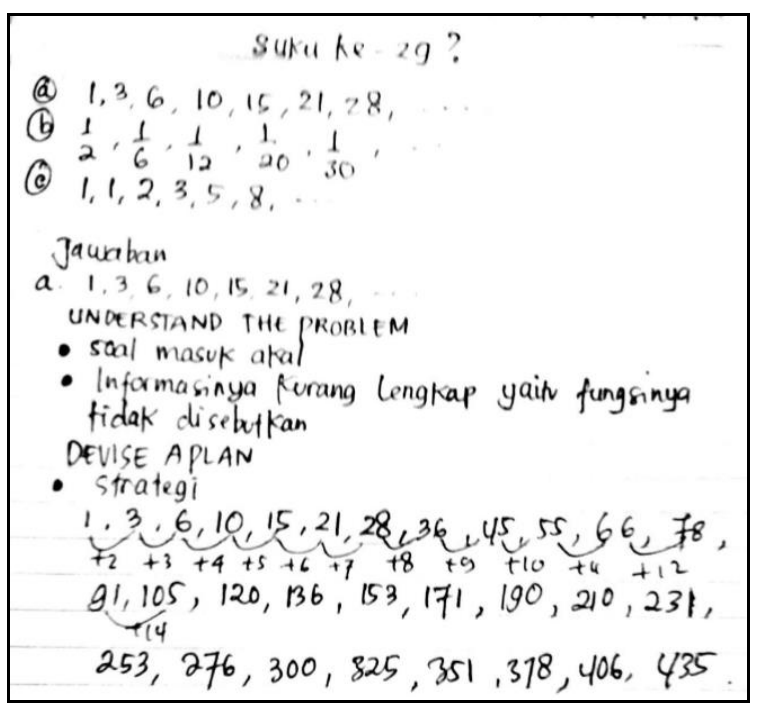

Picture 2. SS' Answer

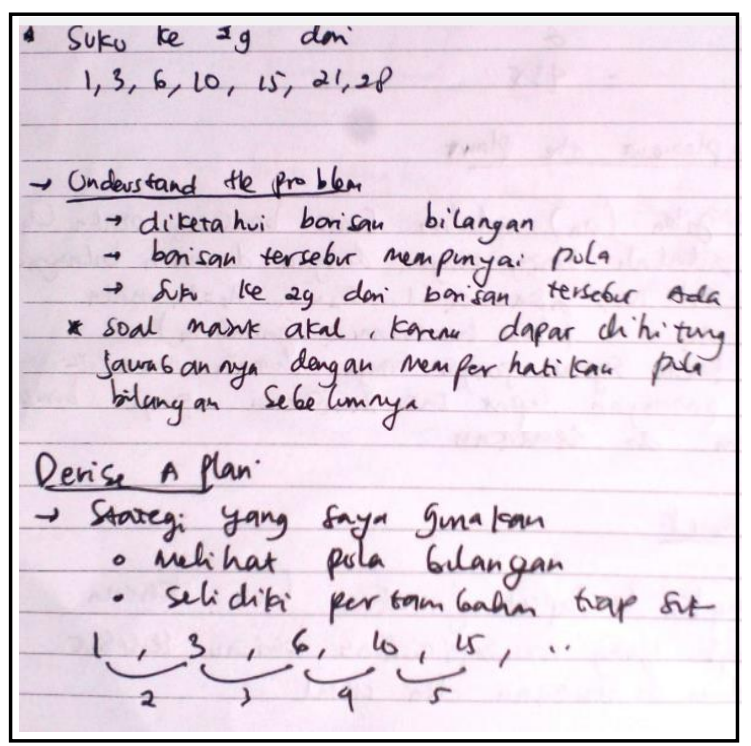

Picture 3. FT' Answer

Based on the answers of the two students above, it can be seen that the two students have not indicated that they have the ability to think critically, because they immediately claim that the line is a multilevel line even though there is no such information in the problem. A person who thinks critically can provide several alternative answers to the problem, as follows:

1. If the line repeats:

$$
1,3,6,10,15,21,28,1,3,6,10,15,21,28, \ldots
$$

Then the 29th tribe is 1

2. If the sequence is the same after a certain term:

$1,3,6,10,15,21,28,28,28,28,28, \ldots$

Then the 29th tribe is 28

In line with As'ari et al (2017) they do not try to make different perspectives and produce possible solutions. This is one reason researchers say that the two subjects do not yet have the ability to think critically. Furthermore, after obtaining two research subjects, researchers explored more deeply how the development of the subject's critical thinking ability by looking at the work of the research subject in the 5th and 10th assignments then continued with an interview to see indicators of critical thinking abilities that have not yet emerged. The following is described the ability to think critically of the 2 subjects studied.

\section{The critical thinking skills of SS and FT in doing assignment 5}

As explained earlier, researchers only focus on indicators of evaluation, inferences, explanation and self-regulation. Following are the details of each indicator of critical thinking ability from SS and FT when solving problems.

a. Evaluation

The answer of SS' can be viewed on picture 4 below

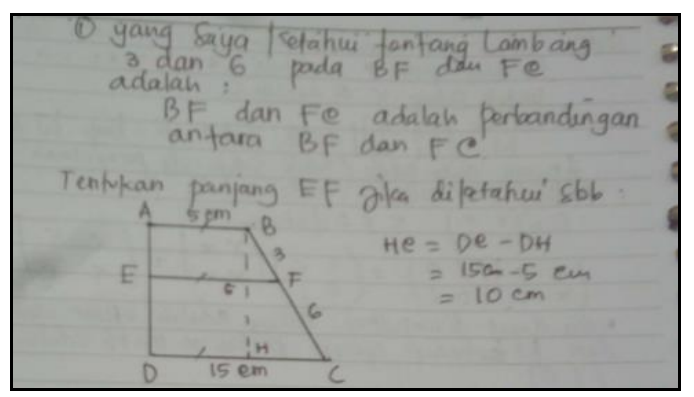

Picture 4. SS' Answer for Task 5

SS subjects wrote that symbols 3 and 6 at $\mathrm{BF}$ and $\mathrm{FC}$ are comparisons. This indicates 


\section{JIPM (Jurnal Ilmiah Pendidikan Matematika), 6(1), September 2017- 17}

Ika Krisdiana, Edy Suprapto

that SS is able to evaluate the problem well. Furthermore, researchers conducted interviews with SS regarding the evaluation process he wrote. Here are the results of the interview:

Q : Why do you say what I know about symbols 3 and 6 at $\mathrm{BF}$ and $\mathrm{FC}$ as a comparison?

SS : Because there is no unit in the matter.

Q : Is there no unit, it means a comparison?

SS : .. (silent and thinking) seems like that.

Based on the results of the interview, it can be seen that SS is able to evaluate well even though it cannot provide a good enough reason.

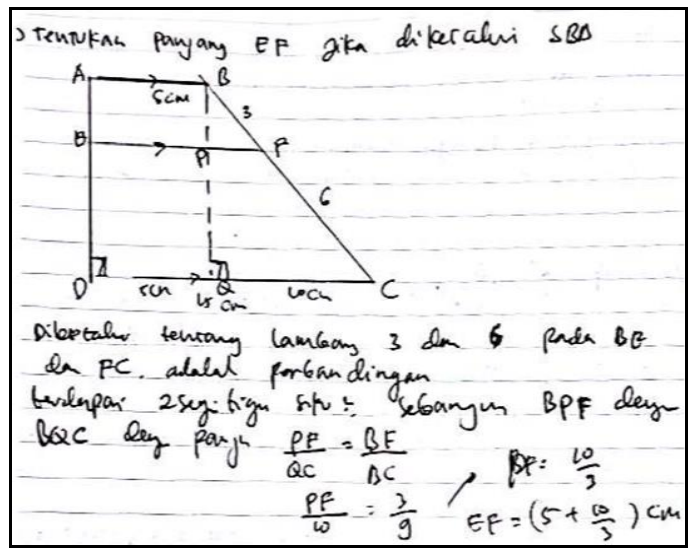

Picture 5. FT' Answer for Task 5

FT subjects wrote that it is known that symbols 3 and 6 at $\mathrm{BF}$ and $\mathrm{FC}$ are comparisons. Whereas in the matter of lack of information, to obtain clearer information, an interview was conducted, along with the results of the interview.

Q : Where do you know that the 3 and 6 symbols in the picture are a comparison between $\mathrm{BF}$ and FC

FT : Because it is seen in the picture, 3 and 6 do not have a unit of length, in contrast to the mark on the $\mathrm{AB}$ line segment which is $5 \mathrm{~cm}$. In addition, because the length of the front side of the right angle is longer than the length of the other side, the triangle $\mathrm{BQC}$ length $\mathrm{CQ}=$ $10 \mathrm{~cm}$, so it is not possible the length of $\mathrm{BQC}<10 \mathrm{~cm}$
Based on the results of the interview, it was seen that FT was able to evaluate well, this was evident from the presentation presented, presented logically and validly.

Based on the data above shows that both subjects both SS and FT are very thorough in evaluating the relationship of numbers 3 and 6 in the figure, this is in line with the opinion of Paul \& Elder (2009) which states that accuracy is an intellectual standard used to determine quality from the results of one's reasoning in evaluating.

b. Inferences

SS is able to do inferences well, conclusions taken through logical reasoning are correct. The following are the results of interviews with researchers with SS to identify whether conclusions are taken through the correct premise.

Q : What triangles do you mean?

SS : ee ... that is a comparison of two matching triangles there, $\mathrm{BGF}$ is in line with BHC

Q : Why is BGF compatible with BHC triangles?

SS : Because the corresponding angles are equal, the corresponding sides are the same comparison

FT is able to do inferences well, conclusions taken through logical reasoning are correct. The following are the results of interviews with researchers with FT to identify whether conclusions are taken through the correct premise.

Q : If you use $\mathrm{ABEF}$ and EFCD directly to find the length, BF may not?

FT : It is not permissible because there is no information that the $\mathrm{ABEF}$ build was in line with EFCD

Q : So what do you use to determine the length of EF?

FT : Using the similarity relationship between triangle $\mathrm{BPF}$ and triangle BQC 
Q : How do you know the two triangles are congruent?

FT : Because the corresponding angles are the same size sir.

Based on the description above it can be seen that the subject's understanding of the concept of congruence has been good so that it can provide a good explanation, this is in line with the opinion (Carson, 2007; Peter, 2012; Snyder \& Snyder, 2008) which states that basic knowledge influences students' ability to complete problem.

\section{c. Explanation}

The process of explanation of the two subjects can be seen in its entirety from the presentation of the work on the answer sheet and the results of interviews conducted when the subject is asked to explain the steps they have taken to solve the problem. Based on the data obtained from the answer sheet and interview shows that both subjects can present the answer well.

\section{d. Self-Regulation}

Self-regulation is the last indicator of critical thinking ability, this indicator is sometimes not seen in students' written answers so they need to be identified through interviews. The following are the results of interviews conducted by researchers to see the Self-Regulation of SS:

Q : After you know that the triangle is congruent then you use a comparison of the sides of a triangle that is congruent, until you find $E F=\left(5+\frac{10}{3}\right) \mathrm{cm}$, are you sure of what you are doing?

SS : When working on the problem, I did not check again, if I check again now.

Q : Then now what are you sure about the answer, ma'am?

SS : It looks like, the small triangle is the sloping side 3 while EF finds $10 / 3$ seems wrong because the hypotenuse should be the longest side (think again)
Q : So how come ma'am?

SS : Oh no, 3 I assume it's not BF length but a comparison between $\mathrm{BF}$ and FC. So it's okay if GF is $10 / 3 \mathrm{~cm}$

Q : So how now what are you sure of your answer?

SS : Yes, sir.

Based on the interview above, it can be seen that the SS subject is able to do selfregulation, namely the ability to correct the mistakes he made. The following are the results of interviews conducted by researchers to see the Self-Regulation of FT:

$\mathrm{P} \quad$ : After it is processed, finally, $\mathrm{Mr}$. FT found that $\mathrm{EF}=5+10 / 3 \mathrm{~cm}$, is sure of this answer?

FT : Yes

$\mathrm{P} \quad$ : Does this answer make sense?

FT : Yes, it makes sense

$\mathrm{P}$ : How can it make sense?

FT : If this is for example I multiply 3 then the length of $3 \mathrm{EF}=15+10$ $=25 \mathrm{~cm}, 3 \mathrm{AB}=15$ and $3 \mathrm{DC}=45$ $\mathrm{cm}$. be EF length between $\mathrm{AB}$ and DC length

$\mathrm{P} \quad$ : Fine sir, thank you

Based on the interview above, it can be seen that the FT subject is capable of selfregulation, namely the ability to re-examine the answers that have been found.

\section{The critical thinking skills of SS and FT in doing task 10}

As explained earlier, researchers only focus on indicators of evaluation, inferences, explanation and self-regulation. Following are the details of each indicator of critical thinking ability from SS and FT when solving problems.

\section{a. Evaluation}




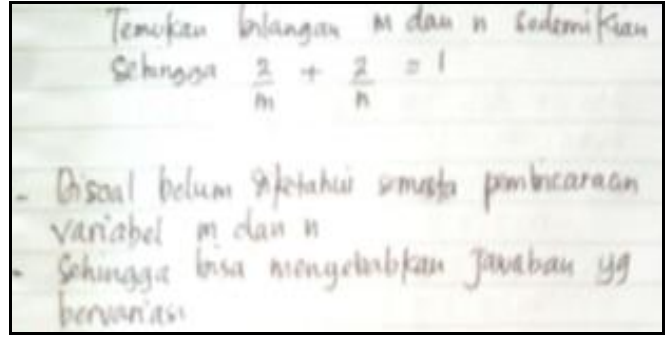

Picture 6. SS' Answer for Task 10

The SS subject wrote that the universe of speech $\mathrm{m}$ and $\mathrm{n}$ had not been mentioned, so that it could cause a variety of answers. This indicates that SS is able to evaluate the problem well.

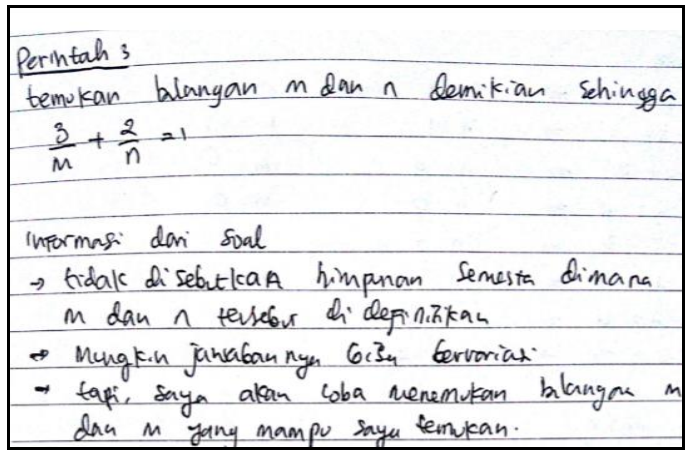

Picture 7. FT' Answer for Task 10

FT subjects wrote that the universe set $\mathrm{m}$ and $\mathrm{n}$ were not mentioned and said that the answer could vary. This indicates that the FT is capable of evaluating the problem well.

\section{b. Inferences}

$\mathrm{SS}$ is able to do inferences well, conclusions taken through logical reasoning are correct. Each answer obtained is based on the universe of speech $\mathrm{m}$ and $\mathrm{n}$. for example when $\mathrm{m}, \mathrm{n}$ integers, $\mathrm{m}, \mathrm{n}$ natural numbers, or $\mathrm{m}, \mathrm{n}$ real numbers. Similar to SS, FT subjects are able to do inferences well, conclusions taken through logical reasoning are correct. FT answers by dividing several cases including when $m$ and $n$ natural numbers, $m$ and $n$ integers, $m$ and $n$ modulus numbers 4 , and at the time of $\mathrm{m}$ and $\mathrm{n}$ real numbers. The FT subject made a mistake when writing the condition $\mathrm{m}, \mathrm{n}$ at the time of universe $\mathrm{m}, \mathrm{n}$ was a real number, but at the time of interviewing the FT subject realized his mistake. The following are the results of interviews with researchers with FT:

$\mathrm{P}$ : Then the FT process until finally obtained, is the value of $m$ available for all $n$ ?

FT : If $\mathrm{n}$ is not equal to 2 there is no

$\mathrm{P}$ : Why isn't it here

FT : Oh yes sir there should be

c. Explanation

The explanation process of both subjects can be seen as a whole from the presentation of the work on the answer sheet and the results of interviews conducted when the subject is asked to explain again the steps they have taken to solve the problem. Based on the data obtained from the answer sheet and interview shows that both subjects can present the answer well.

\section{d. Self-Regulation}

Self-regulation is the last indicator of critical thinking ability. For this problem, SS is seen as doing self-regulation by checking the answers, as seen from the following SS work:

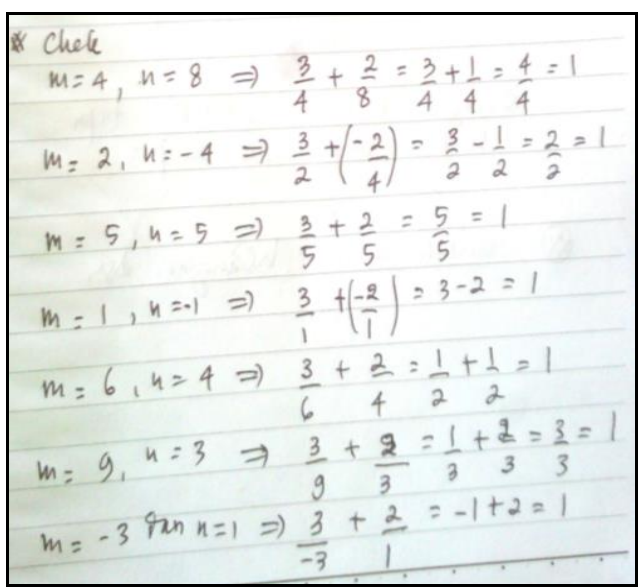

Picture 8. SS' Answer for Task 10

TF conducts self-regulation by checking the results obtained, as shown in the TF work results below: 


cek haril
$n=3, m=9$
$\frac{3}{9}+\frac{2}{3}=\frac{1}{3}+\frac{2}{3}=1 \quad$ benor
$n=1, m=-3$
$\frac{3}{-3}+\frac{2}{1}=-1+2=1 \quad$ henor
$n=4, m=6 \quad$ henor
$\frac{3}{6}+\frac{2}{4}=\frac{1}{2}+\frac{1}{2}=1 \quad$ tidal benor
$n=0, m=0 \quad$ henor
$\frac{3}{0}+\frac{2}{6}=$
$n=5+m=5$
$\frac{3}{5}+\frac{2}{5}=\frac{5}{5}=1$

Picture 9 FT' Answer for Task 10

\section{CONCLUSION}

Based on the results of data analysis in the results and discussion subchapters it can be concluded that for both SS and ST research subjects experienced an increase in their critical thinking skills, this can be seen from each indicator critical thinking evaluation, inferences, explanation, and self-regulation. In each indicator of critical thinking the research subject is able to demonstrate the

\section{REFERENCES}

Akgun, A., \& Duruk, U. (2016). The Investigation of Preservice Science Teachers' Critical Thinking Dispositions in the Context of Personal and Social Factors. Science Education International, 27(1), 3-15. Retrieved from https:// files.eric.ed.gov/fulltext/EJ1100164.pdf Aktaş, G. S., \& Ünlü, M. (2013). Critical Thinking Skills of Teacher Candidates of Elementary Mathematics. Procedia - Social and Behavioral Sciences, 93, 831-835. https://doi.org/10.1016/j.sbs pro.2013.09.288

As'ari, A. R., Mahmudi, A., \& Nuerlaelah, E. (2017). Our Prospective Mathematic Teachers Are Not Critical Thinkers Yet. Journal on Mathematics Education, 8(2), 145-156. https://doi.org/10.223 42/jme.8.2.3961.145-156

Asari, A. R. (2014). Ideas for Developing Critical Thinking at Primary School ability to do evaluation, inferences, explanation, and self-regulation, this is certainly very different from the initial conditions of the research subjects where they have not been able to do evaluations, inferences, explanation well. One of the things that allows an increase in critical thinking skills is the subject of teaching and learning activities, one of which is the provision of tasks that require students to exercise their critical thinking skills.

The results of this study provide an overview to lecturers, teachers and researchers that giving certain questions can improve critical thinking skills. It is expected that lecturers, teachers and researchers can design and develop questions specifically designed to stimulate students' critical thinking skills. In addition, it is expected that lecturers or teachers should always involve students in critical thinking, by giving assignments that contain critical thinking, monitoring students' critical thinking abilities by giving tests of critical thinking skills, then providing evaluation with students so that students are equipped with critical thinking skills.

Level, (March), 1-13. https://doi.org/ 10.13140/2.1.4534.9921

Carson, J. (2007). A problem with problem solving. Teaching Thinking without Teaching Knowledge, 17(2), 7-14.

Chukwuyenum, A. N. (2013). Impact of Critical thinking on Performance in Mathematics among Senior Secondary School Students in Lagos State. Journal of Research \& Method in Education, 3.5(5), 18-25.

Cottrell. (2005). Developing Effective Analysis and Argument. Library.

Ebiendele Ebosele Peter. (2012). Critical thinking: Essence for teaching mathematics and mathematics problem solving skills. African Journal of Mathematics and Computer Science Research, 5(3), 39-43. https://doi.org/ 10.5897/AJMCSR 11.161

Emir, S. (2009). Education faculty students' 
critical thinking disposition according to achedemic achievement, 1(1), 2466 -2469. https://doi.org/10.1016/j.sbspro .2009 .01 .433

Ennis, R. H. (2011). The Nature of Critical Thinking: An Outline of Critical Thinking Dispositions. University of Illinois, 1-8.

Ennis, R. H. (2011). The Nature of Critical Thinking: An Outline of Critical Thinking Dispositions. University of Illinois, 1-8.

Facione, P. A. (1990). Critical Thinking: A Statement of Expert Consensus for Purposes of Educational Assessment and Instruction Executive Summary " The Delphi Report. The California Academic Press, 423(c), 1-19. https:// doi.org/10.1016/j.tsc.2009.07.002

Firdaus, Kailani, I., Bakar, M. N. bin, \& Bakry. (2015). Developing Critical Thinking Skills of Students in Mathematics Learning. Journal of Education and Learning, 9(3), 226236. https://doi.org/10.11591/edulearn .v9i3.1830

Hidayanti, D. (2016). Analisis kemampuan berpikir kritis siswa smp kelas ix pada materi kesebangunan. Konferensio Nasional Penelitian Matematika Dan Pembelajaran, 2502-6526(Knpmp I), 276-285.

Jacob, S. M. (2012). Mathematical achievement and critical thinking skills in asynchronous discussion forums. Procedia - Social and Behavioral Sciences, 31(2011), 800-804. https:// doi.org/10.1016/j.sbspro.2011.12.144

Palinussa, A. L. (2013). Students' Critical Mathematical Thinking Skills and Character: IndoMS. J.M.E, 4(1), 75-94.

Paul, R., \& Elder, L. (2009). The Miniature Guide To Critical Thinking. https://doi .org/10.1002/pfi.4170340606

Rasiman. (2015). Leveling of Critical Thinking Abilities of Students of Mathematics Education in Mathematical Problem, 40-52.

Rosnawati. (2015). A Formative Assessment Model Of Critical Thinking in Mathematics Learning in Junior High School. Research and Evaluation in Education Journal, 1(1), 13-24.

Ruggiero. (2012). Beyond Feelings A Guide To Critical Thinking (Ninth Edit). New York: McGraw-Hill.

Snyder, L. G., \& Snyder, M. J. (2008). Teaching Critical Thinking and Problem Solving Skills How Critical Thinking Relates to Instructional Design. The Delta Pi Epsilon Journal, 1(2), 90-100.

Watson, G., \& Glaser, E. M. (2010). Watson-Glaser II Critical Thinking Appraisal. 